\title{
Отзывчивость картофеля сорта Невский на возрастающие дозы минеральных удобрений
}

\author{
К.Н. Корляков ${ }^{1 *}$, А.И. Косолапова ${ }^{1}$, Д.С. Фомин ${ }^{1}$, В.Р. Ямалтдинова ${ }^{1}$, \\ А.Ф. Сметанников ${ }^{2}$ \\ ${ }^{1}$ ПНИИСХ УрО РАН, Пермь, Россия \\ ${ }^{2}$ ГИ УрО РАН, Пермь, Россия \\ *e-mail:pniish@rambler.ru
}

Установлена высокая отзывчивость картофеля сорта Невский на возрастающие дозы минеральных удобрений на дерново-среднеподзолистой среднеокультуренной почве с содержанием гумуса 2,2 \%, подвижного фосфора 172, обменного калия 124 мг/кг почвы, $\mathrm{pH}=5,01$.

Сбалансированное питание позволяет формировать высокую урожайность картофеля с хорошими качественными показателями клубней.

Урожайность картофеля в опыте, несмотря на неблагоприятные агрофизические показатели почвы (высокая плотность, низкое содержание агрономически ценной фракции), была высокой. В среднем за 2 года картофель сформировал урожайность $10,83-25,8$ т/га. Максимальная урожайность $(25,8$ т/га) отмечена в варианте с внесением NPK по 150 кг д.в./га. Однако прибавка урожайности клубней картофеля в этом варианте не имела существенного преимущества перед внесением минеральных удобрений в дозе NPK по 90 кг д.в./га. В этом же варианте отмечена наиболее высокая окупаемость прибавкой урожая 47,8 т/га за 1 кг д.в., внесенного NPK. Высокие дозы удобрений (120-150 кг д.в/га) ухудшали качество клубней картофеля: снижалось содержание крахмала, сухого вещества и витамина С. Возрастающие дозы минеральных удобрений способствовали не только формированию высокого урожая клубней картофеля, но и обеспечивали улучшение агрохимических и агрофизических свойств почвы. Внесение минеральных удобрений NPK 60 кг д.в./га и выше способствовало существенному повышению содержания гумуса, накопление которого происходило за счет запашки в почву ботвы картофеля и корневых остатков, а также усиления микробиологической деятельности почвенной микрофлоры. Внесение высоких доз минеральных удобрений 90 кг д.в./га и выше обеспечило достоверное увеличение содержания подвижного фосфора и обмененного калия, однако приводило к подкислению почвы: показатель рН снизился с 5,01 до 4,54.

Минеральные удобрения косвенно повлияли на агрофизические свойства дерновосреднеподзолистой почвы: благодаря интенсивному развитию макробиоценоза и формированию мощной корневой системы картофеля повысилось содержание агрономически ценной макро- и микроструктуры. Сбалансированное питание растений способствовало также увеличению водопрочных агрегатов, отмечено существенное увеличение этого показателя по сравнению с контролем.

Таким образом, повышение содержания гумуса, подвижного фосфора и обменного калия и улучшение агрофизических свойств почвы способствовало устойчивости растений к неблагоприятным климатическим условиям и формированию высокой урожайности картофеля.

Благодарности: Работа выполнена при финансовой поддержке программы КПНИ «Картофель». 